\title{
Metode Studi Ilmu Al-Qur'an Kontemporer: Respon Terhadap Pandangan Orientalis Pada Al-Qur'an
}

\author{
Irzak Yuliardy Nugroho \\ Universitas Islam Zainul Hasan Genggong Probolinggo \\ Jl. Raya Panglima Sudirman No.360, Semampir, Kraksaan, Probolinggo, Jawa Timur, Indonesia 67282 \\ ardhiesjb@gmail.com \\ Imam Syafi'i \\ Universitas Islam Zainul Hasan Genggong Probolinggo \\ Jl. Raya Panglima Sudirman No.360, Semampir, Kraksaan, Probolinggo, Jawa Timur, Indonesia 67282 \\ afafzuhri@gmail.com
}

\begin{abstract}
The historical nature of the Qur'an led to the emergence of hermeneutical ideas and theories (methods of interpretation). This theory is a very urgent effort to be developed in understanding the meaning of the Qur'an as a whole. The hope is that the theological and legal ethical parts can be placed in a unified whole (total). Through this method, a weltanschauung (worldview) of the Qur'an can be formulated and understood. If humans want to think optimally and want to use their rational mind, they will realize that in fact the greatest blessing of the Qur'an is the thought and understanding of the intentions and meanings contained therein to then realize their ideas in actions that are both religious and spiritual. In this case, then Sahiron Syamsuddin, mapped the flow of contemporary Qur'anic study methods into three groups: a) The traditionalist quasi-objectivist view; b) The modernist quasi-objectivist view; c) Subjectivist views. The study of the science of the Qur'an in the West was first carried out by the Orientalism group, which at the beginning of its emergence was closely related to the psycho-historical relationship between Islam and the West in the intellectual, trade and war fields. Therefore, the study of the science of the Qur'an in the study of orientalism is not only oriented to the emotional-intellectual relationship, but also the emotional-political east, namely in order to facilitate the political expansion of the West towards the East. But along with the times, orientalism in the end moved purely on an objective-independent study of the east. The flow of orientalism, at least, goes through three periods, namely the period before the crusades, the crusades to the European enlightenment period, and the last period from the enlightenment to modern times. This is marked by the presence of orientalists in the East (Islam) who also functioned as colonial advisors, in addition to conducting scientific studies.
\end{abstract}

Keywords: Al-Qur'an, Hermeneutics, Contemporary.

\begin{abstract}
Abstrak
Sifat Al-Qur'an yang bersifat historis menyebabkan munculnya gagasan dan teori hermeneutika (metode penafsiran). Teori ini menjadi kerja-usaha yang sangat mendesak untuk dikembangkan dalam memahami makna AlQur'an secara utuh. Harapannya, bagian-bagian teologis dan etika legalnya dapat ditempatkan dalam keseluruhan (totalitas) yang padu. Melalui metode ini, sebuah weltanschauung (pandangan dunia) Al-Qur'an dapat dirumuskan dan dipahami. Bila manusia mau berpikir secara optimal dan mau memanfaatkan akal rasionalnya, ia akan menyadari bahwa sesungguhnya berkah Al-Qur'an yang teramat besar adalah pemikiran dan pemahaman maksudmaksud serta makna yang terkandung di dalamnya untuk kemudian mewujudkan gagasannya dalam perbuatan yang bersifat keagamaan dan keduaniaan. Dalam hal ini, kemudian Sahiron Syamsuddin, memetakan aliran metode studi qur'an kontemporer menjadi tiga kelompok: a) Pandangan quasi- obyektivis tradisionalis; b) Pandangan quasi-obeyektivis modernis; c) Pandangan aliran subyektivis. Studi ilmu al-Qur'an di Barat pertama kali dilakukan oleh kelompok Orientalisme yang pada awal kemunculannya berkaitan erat dengan psiko- historis hubungan Islam dan Barat di bidang intelektual, perdagangan dan peperangan. Oleh karena itu, studi ilmu al-Qur'an dalam kajian orientalisme tidak hanya berorientasi pada hubungan emosi-intelektual, melainkan juga emosi-politis ketimuran, yaitu dalam rangka memperlancar ekspansi politik Barat terhadap Timur. Tetapi seiring perkembangan zaman, orientalisme pada akhirnya bergerak murni pada kajian ketimuran secara obyektif- independen. Alur perjalanan orientalisme itu, setidaknya, melalui tiga periode, yaitu periode sebelum perang salib, perang salib hingga masa pencerahan Eropa, dan periode terakhir adalah mulai pencerahan hingga zaman modern. Hal ini ditandai dengan kehadiran para orientalis di Timur (Islam) yang juga berfungsi sebagai penasehat kolonial, disamping melakukan kajian-kajian ilmiah.
\end{abstract}

Kata Kunci : Al-Qur'an, Hermeneutika, Kontemporer. 


\section{PENDAHULUAN}

Kitab suci Al-Qur'an sebagai shalihun li kulli zaman wa makan. Ungkapan tersebut tidak saja diakui oleh para ulama tafsir klasik, tetapi juga diakui oleh ulama-ulama tafsir modern kontemporer. Hal inilah yang kedepannya menjadikan diskursus tentang penafsiran al-Qur'an tidak pernah mengenal kata final. Dibuktikan bahwa selama ini, alQur'an sudah diteliti dan dikaji dengan beragam metodologi juga dipraktikkan dan diajarkan dengan aneka macam cara. ${ }^{1}$ Namun bagaikan samudera yang luas dan dalam, alQur'an senantiasa selalu menyesuaikan, tidak pernah kering dan gersang, walaupun telah, sedang dan akan terus di kaji dari berbagai sudut pandang dan metodenya. Aktifitas untuk mempelajari dan menggali studi ilmu al-Qur'an tidak saja menggaung di dunia Islam, juga menarik perhatian para peneliti di belahan bumi bagian Barat (Orientalisme). ${ }^{2}$

Bagaimana tuntutan seharusnya al-Qur'an sebagai tuntunan dan pegangan untuk masyarakat muslim dapat memiliki fungsi juga peran dengan baik, terutama pada era modern tidak akan bisa mencapai titik finalnya. Karena itulah, tidak cukup apabila alQur'an sebatas hanya disimak dan dibaca sebagaimana aktifitas rutin belaka dalam berkehidupan setiap harinya tanpa memiliki kemampuan untuk memahami prinsip-prinsip, konteks serta segala apa yang ada di dalamnya. Proses panjang bagaimana upaya mempertahankan isi al- Qur'an dan upaya untuk menjadikannya selaras dengan realita keadaan zaman adalah sebuah keniscayaan. Yang mana salah satu upayanya adalah bagaimana selalu berusaha untuk menjalankan dalam berkehidupan di era modern ini $^{3}$, yaitu memaknai sesuai dengan realitas dan kondisi sosial masyarakat saat ini.

Kenyataan bahwa Indonesia sebagai sebuah negara dengan masyarakat mayoritas muslim, tentu memberikan andil signifikan terhadap progress perkembangan studi keislaman, termasuk di dalamnya adalah studi ilmu al-Qur'an. Pada studi ilmu al-Qur'an, banyak cendekiawan di Indonesia yang melahirkan banyak sekali karya dalam bidang tafsir al-Qur'an. Sebuah tafsir lahir dengan beranekaragam corak dan metodologi menandai bahwa setiap karya tafsir punya karakteristik yang beranekaragam. Dewasa ini hermeneutika menjadi sebuah gaya baru sebagai sebuah corak dan metodologi penafsiran

\footnotetext{
${ }^{1}$ Lihat Ayatullah Sayyid Kamal Faghih Imani dalam Nur al-Qur'an: An Enlightening Commentary Into The Light Of The Holy Qur'an (Iran: Imam Ali Public Library, 1998), 16.

${ }^{2}$ Lihat Fazlur Rahman, "Some Recent Books on the Qur'an by Western Authors," Jurnal of Religion, Vol. 64, 1984, 73.

${ }^{3}$ Lihat M. Quraish Shihab, Membumikan al-Qur'an: Fungsi dan Peran Wahyu dalam Kehidupan Masyarakat (Bandung: Mizan, 2003), 88.
} 
era kontemporer, juga di Indonesia. Lantas, bagaimanakah basic dan pondasi dari metodologi hermeneutika yang mana kedepannya dapat memunculkan berbagai tipologi tafsir yang beranekaragam? Seperti apakah langkah yang ideal sebagai solusi dalam menjawab tantangan zaman sesuai dengan ungkapan sholihun likulli zaman wa makan? Tulisan ini disusun dalam rangka 'kritisme' yang mana diharapkan kedepannya dapat menemukan sebuah sintesa terhadap macam tipologi dan metodologi yang terdapat pada sebuah penafsiran al-Qur'an. Hasil dari sebuah sintesa yang mana diharapkan kedepannya dapat menjadi sumbangsih ilmu pengetahuan dalam kajian ilmu al-Qur'an di zaman modern (kontemporer) di Indonesia. Yang mana selanjutnya sebuah tipologi dan metodologi tafsir yang dialektis, kritis, reformative, dan transformative akan dirumuskan, sehingga diharapkan produk dari penafsiran tersebut dapat menjadi solusi akan berbagai, pertanyaan, dan problematika modern yang dialami dan dihadapi masyarakat dewasa ini. Pada akhir abad ke 20 bermunculan para tokoh yang memiliki pemikiraN progresif dari kalangan muslim yang mejadikan al-Qur'an sebagai kajian dan pusat wacana. ${ }^{4}$

Ide progresif pemikiran Islam dan tafsir ada didalamnya yang digawangi oleh para tokoh kontemporer muncul dari beberapa keresahan dan kegelisahan, adalah misalnya: (1) Tafsir yang ada dan berkembang sampai saat ini belum terlalu mengakomodasi kehidupan masyarakat dari perspektif keadilan masyarakar, pembelaan terhadap keterlibatan perempuan dan gender, kaum minoritas, kasus hukum (korupsi, kolusi dan nepotisme) dan HAM (2) kenyataan masyarakat yang tidak tertata, bahkan mundur, karena sebagian dari masyarakat hanya mengkonsumsi produk dari tafsir-tafsir klasik, yang bisa sangat mungkin beberapa sudah tidak relevan lagi dengan kondisi realitas masyarakat.

Ironis bahwa studi kritik terhadap tipologi dan metodologi belum menjadi agenda rutin dari kalangan cendikiawan muslim. Mereka lebih condong kepada eksegese, yakni komentar terkait problematika teks dan bersifat praksis, daripada tentang kajian

${ }^{4}$ Diantaranya Muhammad 'Âbid al-Jâbirî, Muhammad Arkoen, Fazlurrahmman, Nasr Hamid Abu Zaid, Muhammad Syahrûr, Farid Esack, Abdullah Saeed, Muhammad Talbi dan Hasan Hanafi. Para pemikir progresif muslim tersebut menawarkan gagasan yang menjadi ciri khas masing-masing, yaitu sebagai berikut: (a) Fazlur Rahman mengusung teori "double movement"; (b) Mohammad Arkoun menggagas kritik nalar Islam; (c) Hasan Hanafi menggagas kiri Islam; (d) Abid al-Jabiri mencetuskan kritik nalar Arab; (e) Nasr Hamid Abu Zaid mengusung kritik wacana agama; (f) Muhammad Syahrur menggagas al-kitâb wal Qur'ân: Qirâ'ah muâ'assirah; (g) Muhammad Talbi menggagas 'iyal Allah (Keluarga - Keluarga Tuhan), dan demikian pula dengan pemikir muslim lainnya. Lihat Sahiron Syamsuddin, Hermeneutika Al-Qur'an Dan Hadist, (Yogyakarta; Elsaq Press, 2010), 89 
hermeneutika yang mengkhususkan terhadap masalah metodologi dalam menafsirkan dan lebih bersifat teoritik. ${ }^{5}$

Problematika terkait metodologi masih menjadi bidang yang belum mendapatkan perhatian yang maksimal, meskipun pada kampus-kampus perguruan tinggi Islam. Sebuah metodologi adalah salah satu unsur bagian dari epistemologi yang fokus pada langkah sistematis yang ditempuh agar ilmu pengetahuan didapat memenuhi kriteria-kriteria ilmiah. Tentang hal ini, metodologi sendiri didapatkan dan dipandang sebagai unsur dari ranah logika yang mengkaji beberapa kaidah penalaran yang tepat. Prinsip metodologi dalam hal ini, tidak lagi dimaksud sekedar langkah metodis belaka, tetapi asumsi logis yang akan menggaungi akan munculnya sebuah metode baru. ${ }^{6}$

Tradisi untuk berpikir kreatif, kritis, dan innovative dalam tujuan mengembangkan, menguji, menata ulang, bahkan mampu membangun ulang teori dan pemikiran sebelumnya, baiknya dilaksanakan tanpa tekanan baik psikologis atau teologis tertentu. Penilaian objektif hanya dapat dilakukan apabila asumsi negatif dan pra-anggapan berhasil diminimalisir dari fikiran kita. Karenanya, penilaian objektif harus mengedepankan dan mengutamakan rasionalitas, dan harus tetap mengupayakan agar dapat memahami isi dari al-Qur'an melalui berbagai macam pendekatan metodologi modern dan terbarukan senantiasa berkembang dan diharapkan tidak berhenti pada sebuah titik saja. ${ }^{7}$

\section{KONSEP METODE STUDI QUR'AN KONTEMPORER}

Hermeneutika, sebagai salah satu wacana pemikiran Islam kontemporer ditawarkan sebagai sebuah tawaran atas stagnasi metodologi Islam sudah merupakan suatu keniscayaan. Tokoh-tokoh pemikir progresif Islam kontemporer ${ }^{8}$ tidak jarang mengingkatkan urgensi metode ini. ${ }^{9}$ Dasar asumsi dari tokoh pemikir metodologi hermeneutika didasarkan pada pemahaman dengan perantara menggunakan metode klasik konvensional pada sumber otoritatif dalam ajaran Islam dianggap kurang tepat untuk kondisi masyarakat dewasa ini, oleh karenanya metode tersebut dirasa perlu dikolaborasikan dengan menggunakan metode kontemporer, yang mana terdapat pada

5 Lihat Muhammad Syahrur, Prinsip Dan Dasar Hermeneutika Al-Qur'an Kontemporer, (Yogyakarta: Teras, 2008), Xvi

${ }^{6}$ Lihat Muhammad Syahrur, Prinsip Dan Dasar Hermeneutika Al-Qur'an Kontemporer, .Xvi

${ }^{7}$ Lihat Muhammad Syahrur, Prinsip Dan Dasar Hermeneutika Al-Qur'an Kontemporer, .Xvi

${ }^{8}$ Seperti Arkoun, Nasr Hamid Abu Zayd, Hasan Hanafi, Amina Wadud Muhsin, Fatima Mernissi, Muhammad Shahur, Lihat Farid Esack, Qur'an, Liberation and Pluralism: An Islamic Perspektive of Interreligious Solidarity against Oppression, (Oxford: Oneworld,1997).

${ }^{9}$ Lihat Farid Esack, Qur'an, Liberation and Pluralism: An Islamic Perspektive of Interreligious Solidarity against Oppression, (Oxford: Oneworld,1997). 
metode hermeneutika. Akan tetapi, yang menjadi kendala adalah, apakah mungkin hermeneutika yang terkena stigma dan dilabeli bukan 'produk dari Islam' dapat mendorong dan berkolaborasi dengan metode konvensional, sebagai usaha memahami sumber otoritatif dalam ajaran Islam, yang mana dalam konteks pembahasan ini adalah metode studi ilmu al-Qur'an? Pijakan dasar gagasan hermeneutika pada al-Qur'an modern kontemporer ini diharapkan pada nantinya akan memunculkan yang dikenal dengan metodologi dan tipologi tafsir.

Gagasan metode hermeneutika disandarkan pada pemahaman teks, konteks, dan kontekstualisasi. Gagasan tersebut telah disadari oleh para mufassir klasik. Pemahaman dan kajian pada teks, menjadi sebuah instrumen dasar oleh para ahli tafsir dan usuli. Kontekstualisasi sendiri tidak luput dari perhatian para peneliti dan pengkaji studi alQur'an era klasik. Kajian tentang konsep maqashid al-syari'ah atau maslahah dapat include pada pembahasan ini. Maqasid al-syari'ah sendiri dikenal sebagai produk hasil ijtihad atau produk hasil penafsiran para mujtahid dapat membawa maslahah dan manfaat bagi masyarakat. Kitab-kitab ushul fikih klasik karya Sarjana Muslim memberikan signifikansi sumbangsih mengenai hal tersebut.. ${ }^{10}$

Martin Heidegger seorang filsuf (1889-1976) memposisikan metode hermeneutika dalam ranah pembahasan ontologi. Menurutnya, manusia ada untuk saling memahami, yang membedakannya dengan makhluk yang lain. Progres awal mula perkembangan hermeneutic modern adalah sejak Schleirmacher sampai Paul Ricoeur, yang lambat-laun dikenal sebagai hermeneutic barat. Paul Ricoeur mengembangkan metode hermeneutika sebagai sebuah metodologi yang digunakan sebagai media untuk melihat dan meneliti tindakan perilaku manusia. ${ }^{11}$

Dalam esainya, Ricoeur mengemukakan dasar asumsi metodologinya, bahwa tindakan yang berasal dari perilaku manusia dinyatakan sebagai sebuah teks yang setara dengan teks-teks tertulis. ${ }^{12}$ Pada perjalanannya, metodologi hermeneutika bukan saja bertujuan untuk menata ulang dan mengeksplorasi pemikiran kreatif dari para penulis teks, tapi sebaliknya, pemahaman makna dari teks sesuai dengan konteks para pembacanya

\footnotetext{
2010), . 4

${ }^{10}$ Lihat Sahiron Syamsuddin, Ed., Hermeneutika Al-Qur'an Dan Hadis, (Yogyakarta: Elsaq Press,

${ }^{11}$ Lihat S. Tjahyadi, Manusia Dan Historisitasnya Menurut Martin Heidegger, Jurnal Filsafat, No. $18 \operatorname{Vol}(1), 2018, .51-63$.

${ }^{12}$ Lihat Syafa'atun Almirzanah \& Sahiron Syamsuddin, Ed., Upaya Integrasi Hermeneutika Dalam Kajian Qur'an Dan Hadis: Teori Dan Aplikasi, (Yogyakarta: Lembaga Penelitian Uin Sunan Kalijaga Yogyakarta, 2009), .8
} 
menghasilkan konstruksi atau produksi. ${ }^{13}$ H.G. Gadamer dan Paul Ricoeur adalah beberapa tokoh filsafat Barat yang turut serta mengembangkan metode hermeneutika konstruktif. Proses memahami teks berdasarkan konteks para pembacanya, sehingga menjadi metode hermeneutika yang memiliki karakteristik mengkonstruksi atau memproduksi pemahaman baru disesuaikan dengan latar konteks situasi pembaca teks saat itu baik secara locus, tempus, dan kondisi sosial. ${ }^{14}$

Karakterikstik Al-Qur'an yang memiliki historisitas, melatarbelakangi timbulnya pemikiran dan teori hermeneutika sebagai paradigma penafsiran. Teori ini menjadi tawaran alternatif dan urgen sebagai pengembangan dalam rangka memahami makna al-Qur'an secara utuh. $^{15}$ Dengan metode ini, kesamaan persepsi utuh tentang al-Qur'an dapat dipahami dan dirumuskan. Apabila manusia menggunakan akal berpikirnya secara maksimal dan memanfaatkan secara optimal rasio akalnya, maka ia akan mengerti dan menyadari bahwa sesungguhnya al-Qur'an memiliki berkah bagi seluruh umat manusia dengan pemikiran dan pemahaman, maksud-maksud serta makna yang terkandung dan terdapat di dalamnya untuk kemudian merefleksikan dalam segala perbuatan baik yang bersifat keagamaan dan bersifat keduniaan. ${ }^{16}$ Apabila dilihat dari tipologinya, maka pembacaan pada masa modern ini, para cendekiawan Muslim, khususnya para pemerhati terhadap studi ilmu al-Qur'an menurut Sahiron Syamsuddin dibagi menjadi tiga kelompok pandangan, yaitu pandangan:

\section{Pandangan Quasi Obyektivis Tradisionalis}

Pandangan quasi obyektifis tradisionalis, adalah sebuah pandangan yang menyatakan bahwa konteks ajaran dari al-Qur'an harus ditafsirkan dan dipahami serta diaplikasikan pada konteks masa kini, sebagaimana pula ia dipahami, ditafsirkan dan diaplikasikan pada situasi kondisi saat ketika al-Qur'an diturunkan dan disampaikan kepada generasi Muslim awal oleh Nabi Muhammad saw. Singkatnya al-Qur'an harus dipahami sesuai dengan tekstual sebagaimana yang terdapat pada teks ayat tersebut dan disesuaikan dengan kondisi zaman di mana ayat tersebut diturunkan. Oleh Sahiron, 50.

${ }^{13}$ Lihat A. K. Soleh, Membandingkan Hermeneutika Dengan Ilmu Tafsir, Tsaqafah, 7(1), 2011, .31-

${ }^{14}$ Lihat S.A. Kau, Hermeneutika Gadamer Dan Relevansinya Dengan Tafsir, Farabi, 11(2), 2014, $.109-123$.

15 Lihat Abd Muid, Dan M. A. Nawawi, Hermeneutika Kesadaran Dalam Memahami Teks AlQur'an, Al Amin: Jurnal Kajian Ilmu Dan Budaya Islam, 3(1), 2020, .83-97.

16 Lihat Ahmad Izzan, Ulumul Qur'an: Telaah Tekstualitas Dan Kontekstualitas Al-Qur'an, (Bandung: Tafakur, 2011). 241-242 
pandangan ini dicontohkan oleh Kelompok Ikhwanul Muslimin dan beberapa kelompok dari kaum salafi yang terdapat pada beberapa negara Islam. Adalah benar ketika kelompok ini menafsirkan ayat ayat dalam al-Qur'an menggunakan beberapa perangkat metode klasik ilmu tafsir seperti ilmu asbabun nuzul, munasabah, naskh wa mansukh, muhkam wa mutasyabih dan lain-lain, akan tetapi mereka mengesampingkan tentang makna kontekstual dalam sebuah ayat. Yang mana hasil penafsiran dari kelompokkelompok ini sepintas kaku dan sangat tekstual. Akibat mengabaikan metode-metode modern kontemporer lain.

Dengan metode yang ada mereka mengharapkan, di balik ayat ditafsirkan terdapat beberapa makna obyektif mampu diungkap dengan baik. Adapun ciri-ciri yang mudah dikenali dari corak penafsiran kelompok ini adalah penafsiran yang cenderung tekstualis. ${ }^{17}$

2. Pandangan Quasi Obeyektivis Modernis

Pandangan quasi obyektivis modernis adalah pandangan memahami terhadap alQur'an dengan menggunakan perantara metode konvensional yang telah ada, seperti asbabun nuzul, munasabah, naskh wa mansukh, muhkam wa mutasyabih dan lain-lain yang sudah ada pada studi ilmu al-Qur'an, dengan melibatkan metode-metode baru modern kontemporer seperti ilmu eksak maupun noneksak (hermeneutika). Menurut Sahiron tipologi ini memiliki kemiripan dengan tipologi quasi obyektivis tradisionalis, yakni bahwa mufasir di masa modern berkewajiban untuk mengungkap asal makna dengan menggunakan metode di luar perangkat metodis ilmu tafsir, juga perangkat metodis lain, seperti tentang konteks sejarah dunia Arab saat penurunan wahyu, teoriteori bahasa dan sastra modern serta hermeneutika. ${ }^{18}$ Manurut Sahiron yang menjadi letak perbedaan adalah aliran quasi-obyektivis modernis asal makna (bersifat historis) hanya sebagai dasar pijakan awal bagi pembacaan al-Qur'an di masa kini, yang mana makna asal dipandang tidak lagi sebagai pesan utama al-Qur'an. ${ }^{19}$ Bahwa pandangan quasi-obyektivis modernis sama sekali tidak mengesampingkan sisi teks dan kontekstualitas al-Qur'an. Pandangan ini diikuti oleh pemikir progresif modern dari kalangan umat Islam, di antaranya dianut oleh Fazlur Rahman dengan konsep yang

\footnotetext{
${ }^{17}$ Lihat Sahiron Syamsuddin, Ed., Hermeneutika Al-Qur'an Dan Hadis, 73.

${ }^{18}$ Lihat Sahiron Syamsuddin, Ed., Hermeneutika Al-Qur'an Dan Hadis, 74-75.

${ }^{19}$ Lihat Sahiron Syamsuddin, Ed., Hermeneutika Al-Qur'an Dan Hadis, 75.
} 
masyhur dikenal sebagai double movement. ${ }^{20}$ Muhammad al-Thalibi dengan konsep yang dikenal al-tafsir al-maqashidi dan Nashr Hamid Abu Zayd dengan konsep yang dikenal al-tafsir al-siyaqi.

Sesuai dengan ungkapan shalihun li kulli zaman wa makan, Al-Qur'an dipandang perlu ditafsirkan sesuai dengan konteks kondisi perkembangan zaman, akan tetapi perlu diingat pula latarbelakang historisnya yang nantinya ditarik penafsirannya di era sekarang. Menurut Sahiron, muslim saat ini harus juga berusaha memahami makna di balik pesan teks, yang disebut oleh Rahman dengan ratio legis, juga disebut dengan maqashid (tujuan-tujuan ayat) oleh al-Thalibi atau disebut maghza (signifikansi ayat) oleh Abu Zayd. Dibalik pesan literal inilah yang harus diimplementasikan baik masa lampau maupun masa yang akan datang. ${ }^{21}$ Di Indonesia sendiri, pada era 2000-an, kelompok quasi-obyektivis modernis sendiri ada beberapa karya tafsir yang muncul, di antaranya adalah: Kontekstualitas Al-Qur'an: Kajian Tematik atas Ayat-ayat Hukum dalam Al-Qur'an, Tafsir Insklusif Makna Islam: Analisis Linguistik-Historis Pemaknaan Islam dalam Al-Qur'an Menuju Titik Temu Agama-agama Semitik, Tafsir Sosial: Mendialogkan Teks dengan Konteks. Tipologi memiliki ciri khas pada produk penafsirannya yang bercorak sosial masyarakat. Yang artinya, produk penafsirannya memiliki orientasi kontekstualisasi ayat dengan tanpa menyampingkan makna asal dari sebuah ayat dan makna historisitas dari sebuah ayat. Misalnya Tafsir Maudhu'i: Solusi Qur'ani atas Masalah Sosial Kontemporer karya dari Nashruddin Baidan. ${ }^{22}$

Tafsir ini mengemukakan tentang bagaimana pentingnya nilai-nilai Al-Qur'an dapat terrealisasikan di tengah kehidupan masyarakat luas. Adapun tema-tema yang diusung pada tipologi tafsir ini adalah tentang isu-isu kontemporer yang berada di tengah-tengah masyarakat. Sehingga tafsir ini terasa lebih membumi dan membaur mudah dalam harmoni di tengah-tengah masyarakat modern.

3. Pandangan Aliran Subyektivis,

Aliran subyektivis beranggapan bahwa pada setiap penafsiran sepenuhnya merupakan subyektivitas dari mufassir, oleh karena itu kebenaran interpretatifnya

\footnotetext{
${ }^{20}$ Lihat Fazlur Rahman, Islam and Modernity : Transformation ofan Intellectual Tradition, (Chicago: University of Chicago Press, 1982), 5-7.

${ }^{21}$ Lihat Sahiron Syamsuddin, Ed., Hermeneutika Al-Qur'an Dan Hadis, 75.

${ }^{22}$ Lihat Nashruddin Baidan, Tafsir Maudhu'i: Solusi Qur'ani atas Masalah Sosial Kontemporer (Yogyakarta: Pustaka Pelajar 2001), 195.
} 
adalah bersifat relatif. $^{23}$ Pada argumen inilah menurut kelompok yang menganut tipologi ini, beranggapan bahwa setiap generasi umat manusia, khususnya umat Islam memiliki hak untuk menafsirkan Kembali al-Qur'an dengan menyesuaikan kondisi masyarakat dan perkembangan zaman. Era saat ini menurut kelompok subyektivis, alQur'an dapat ditafsirkan dengan kolaborasi melalui ilmu-ilmu bantu yang ada dan berkembang pada zaman sekarang tanpa harus melibatkan metode konvensional semata.

Muhammad Shahrur adalah salah satu cendekiawan yang memiliki pandangan subyektivis seperti ini. Shahrur dalam menafsirkan al-Qur'an tidak lagi tertarik untuk mengungkap makna asal dari sebuah ayat atau kumpulan ayat. Seorang mufassir modern, menurutnya harus menafsirkan al-Qur'an dengan menyesuaikan perkembangan ilmu modern, baik dari ilmu eksak maupun non-eksak. ${ }^{24}$ Lumrahnya umat Islam yang mengikuti tipologi pandangan Shahrur ini dikenal dengan predikat "kaum liberal". Oleh karena itu, pandangan ini tidak lagi memerlukan beberapa perangkat metodologi studi ilmu al-Qur'an yang telah ada, seperti asbab al-nuzul, naskh wa mansukh, muhkam dan mutasyabih dan lain sebagainya. Dalam pandangan subyektivis, al-Qur'an cukup ditafsirkan dengan metode dan ilmu-ilmu kontemporer, seperti sosiologi, antropologi, matematika, psikologi dan ilmu-ilmu humaniora lainnya (hermeneutik). Indonesia sendiri belum memiliki tokoh dengan metode penafsiran dengan corak tipologi subyektivis ini.

Maksudnya corak subyektivis dalam sebuah penafsiran pasti ada, namun subyektivis dalam arti bahwa penafsirannya sebagaimana dengan kriteria kerangka teori di atas dengan meninggalkan seluruhnya ilmu konvensional dan semata hanya menggunakan metodologi kontemporer belum ditemukan karya tafsir pada tokoh cendekiawan muslim di Indonesia. Latarbelakang belum ditemukannya corak subyektivis pada karya tafsir di Indonesia salah satunya dipengaruhi oleh beberapa faktor diantaranya adalah masih banyaknya para mufassir yang belum berani melangkah seperti halnya yang dilakukan oleh Shahrur. Selain mereka juga cenderung hati-hati dengan metode kontemporer modern yang ada seperti hermenutika, maka wajar jika metode yang mereka gunakan masih merujuk kepada metode metode yang telah mapan dan ada dalam studi ilmu alQur'an, seperti metode klasik konvensional. Karena bagi mereka, ilmu-ilmu klasik sudah cukup mumpuni dan membantu, serta belum memerlukan metode-metode baru

${ }^{23}$ Lihat Sahiron Syamsuddin, Ed., Hermeneutika Al-Qur'an Dan Hadis, 75

${ }^{24}$ Lihat Sahiron Syamsuddin, Ed., Hermeneutika Al-Qur'an Dan Hadis, 75-76. 
misalnya metode hermeneutika. ${ }^{25}$ Apalagi dengan meninggalkan keseluruhan metode klasik, belum ada satupun mufassir yang berani. Selain itu bisa dikatakan bahwa masih banyaknya para mufasir yang mensakralkan metode klasik, karena metode baru yang melekat dengan stigma "bukan produk Islam" selama ini telah dianggap tidak sah, bahkan ada beberapa yang berani mengharamkan. ${ }^{26}$

Penulis menyoroti tentang bagaimana pemikiran Fazlur Rahman dalam upayanya mengembagkan metode studi ilmu al-Qur'an kontemporer. Beliau adalah pemikir dan tokoh intelektual Islam kontemporer terkemuka. ${ }^{27}$ Kepiawaiannya tergambar dalam gagasan yang dituangkan beliau, diapresiasikan dalam sejumlah karya tulis buku dan artikel, mulai tentang persoalan filsafat, persoalan teologi, persoalan mistik, persoalan hukum hingga sampai pada persoalan perkembangan kontemporer, yang mana sudah tidak syak lagi dan memerlukan beberapa penafsiran baru terhadap kandungan AlQur'an. ${ }^{28}$ Kehidupan modern dan kontemporer mengharuskan beliau untuk senantiasa berpikir keras dalam menemukan solusin demi menyelesaikan masalah-masalah baru yang muncul, untuk mengkaji ulang beberapa paradigma yang terkesan kaku, tidak dialektif ,tidak akomodatif bahkan "sulit" untuk diaplikasikan dalam kehidupan masyarakat. Fazlur Rahman memandang perlunya diadakan interpretasi terhadap alQur'an. ${ }^{29}$ Dalam hal ini, beliau sendiri menawarkan metode tafsir kontemporer yang berbeda dan memiliki ciri khas, daripada metode tafsir sebelumnya. Metode tafsir yang memiliki nuansa "unik" dan menarik untuk dikaji secara intensif dan komprehensif, yaitu metode dari beliau yang populer dikenal dengan nama "Double Movement" atau gerakan ganda. ${ }^{30}$

\footnotetext{
${ }^{25}$ Lihat Sahiron Syamsuddin, Ed., Hermeneutika Al-Qur'an Dan Hadis, . 5-6

${ }^{26}$ Lihat Sahiron Syamsuddin, Ed., Hermeneutika Al-Qur'an Dan Hadis, . 5-6

27 Lihat A. Syukri, Metodologi Tafsir Al-Qur'an Kontemporer Dalam Pemikiran Fazlur Rahman. Kontekstualita: Jurnal Penelitian Sosial Keagamaan, 20(1), 2005.

${ }^{28}$ Lihat R. Irawan, Metode Kontekstual Penafsiran Al-Qur'an Perspektif Fazlur Rahman. AlDzikra: Jurnal Studi Ilmu Al-Qur'an Dan Al-Hadits, 13(2), 2019.

29 Lihat L. Muttaqin, Aplikasi Teori Double Movement Fazlur Rahman Terhadap Doktrin Kewarisan Islam Klasik. Al-Manahij: Jurnal Kajian Hukum Islam, 7(2), 2013.

30 Lihat R. A. Sumantri, Hermeneutika Al-Qur'an Fazlur Rahman Metode Tafsir Double Movement, Komunika: Jurnal Dakwah Dan Komunikasi, 7(1), 2013.
} 


\section{Orientalis dan Pandangannya Tentang Al-Qur'an}

Kata Orientalisme berasal dari orient, kata dalam bahasa Perancis yang secara harfiah bermakna timur dan secara geografis berarti belahan dunia bagian timur juga secara etimologis bermakna bangsa-bangsa dari timur. Kata "orient" sendiri telah masuk di berbagai bahasa di Eropa, termasuk dalam bahasa Inggris. Oriental sendiri adalah sebuah kata sifat dengan makna hal-hal yang bersifat timur, yang luas ruang lingkupnya. ${ }^{31}$

Sedangkan orientalis adalah kata nama tokoh, pelaku yang menunjukkan bahwa seseorang tersebut ahli tentang hal ihwal yang berkaitan dengan "Timur" yang lumrahnya disingkat dengan istilah ahli ketimuran. Sedangkan kata isme berasal dari Bahasa Belanda maupun ism istilah dari Bahasa Inggris, mengarah kepada pengertian tentang suatu paham. Jadi yang dimaksud dengan orientalisme adalah sesuatu paham atau aliran, yang memiliki keinginan meneliti hal yang berkenaan dengan bangsa-bangsa timur beserta lingkungannya. ${ }^{32}$ Menurut Lathifah Ibrahim Khadhar dalam bukunya, seorang orientalis adalah mereka yang mengkaji tentang dunia Timur secara umum, Timur Dekat maupun Timur Jauh, baik dalam bidang Bahasa, sastra, peradaban, budaya maupun agamanya. ${ }^{33}$

Secara terminologis, Edward Said sebagaimana dikutip oleh Idri dalam bukunya menjelaskan ada tiga pengertian dasar orientalisme, yaitu: (1) sebuah cara yang berhubungan dengan bangsa-bangsa Timur berdasarkan tempat khusus Timur dan pengalaman Barat Eropa; (2) corak pemikiran dengan memperhatikan ontologi dan epistemologi Barat secara umum; dan (3) sebuah Langkah yang dilakukan oleh barat untuk mempelajari, membangun kembali kemudian mendominasi apa yang berada di dunia Timur. $^{34}$

Apabila dilihat secara geografis, maka makna kata ini mengarah pada negeri-negeri belahan bumi bagian timur, sebagai arah terbitnya matahari. Negeri-negeri itu terentang dari kawasan timur dekat, yang meliputi Turki dan sekitarnya hingga timur jauh yang meliputi Jepang, Korea dan Indonesia, dan dari selatan hingga republik-republik muslim bekas Uni Soviet serta kawasan Timur Tengah hingga Afrika Utara. Adapun lawan dari kata orient / orientalisme adalah occident / occidentalisme yang berarti arah terbenamnya matahari yang meliputi belahan bumi bagian barat.

\footnotetext{
${ }^{31}$ Irzak Yuliardy Nugroho. Orientalisme dan Hadits : Kritik terhadap Sanad Menurut Pemikiran Joseph Schacht. Asy-Syari'ah : Jurnal Hukum Islam, 6(2), 155-170.

${ }^{32}$ Lihat Joesoef Sou'yb, Orientalisme Dan Islam, (Jakarta: Bulan Bintang, 1995), 1.

${ }^{33}$ Lihat Lathifah Ibrahim Khadhar, Ketika Barat Memfitnah Islam, (Jakarta; Gema Insani, 2005).77.

${ }^{34}$ Lihat Idri, Studi Hadis, (Jakarta: Kencana, 2010), 305-306.
} 
Namun demikian, karena hadirnya Islam menjadi ancaman terhadap Barat, maka pengertian orient dalam konteks pembahasan orientalisme dunia Timur Islam termasuk Andalusia, Sisilia, dan wilayah Balkan, yang secara geografis bukanlah termasuk wilayah Timur. Dengan demikian, orientalisme yang dimaksud adalah sebuah kajian akademis yang dilakukan oleh cendekiawan Barat mengenai Islam dan kaum Muslimin dari seluruh aspeknya, dengan misi untuk membentuk opini umum, sebagai siasat bagaimana bisa menguasai dunia Timur Islam yang memperlihatkan pertentangan dari berbagai macam latar belakang, seperti ideologi, kultur, historis antara belahan bumi bagian Barat dan belahan bumi bagian Timur. ${ }^{35}$ Orientalisme merupakan salah satu bentuk kajian yang dianggap potensi dalam kancah politik dunia Barat bagaimana untuk melawan dominasi Islam dan dominasi kaum muslimin. ${ }^{36}$

Selanjutnya dapat dikatakan bahwasanya orientalisme sendiri sebenarnya adalah bagaimana menyangkut hubungan antara Barat dengan Timur sejak lama. Yang mana hubungan tersebut masih merupakan permasalahan sejak dulu hingga kini. Istilah Barat itu sendiri diciptakan oleh masyarakat Eropa pada era kolonialisme (penjajahan). kolonialisme (penjajahan). Mereka melihat diri sendiri sebagai Barat yang lebih superior daripada Timur yang menjadikan mereka (timur) sebagai obyek yang bisa dtindas untuk kepentingan mereka.

Studi ilmu al-Qur'an di Barat pertama kali dilakukan oleh kelompok Orientalisme yang pada awal kemunculannya berkaitan erat dengan psiko-historis hubungan Islam dan Barat di bidang intelektual, perdagangan dan peperangan. Oleh karena itu, studi ilmu alQur'an dalam kajian orientalisme tidak hanya berorientasi pada hubungan emosiintelektual, melainkan juga emosi-politis ketimuran, yaitu dalam rangka memperlancar ekspansi politik Barat terhadap Timur. ${ }^{37}$

Bisa dikatakan bahwa orientalisme memiliki keterkaitan dengan adanya kolonialisme. Dimana di situ ada kolonialisme, disitu pula ada kajian orientalisme, ditandai semakin luasnya wilayah jajahan, maka akan lebih meluas dan lebih dalam pula gerakan orientalisme mereka. Meluasnya studi tentang orientalisme, erat hubungannya dengan munculnya gerakan-gerakan Islam kontemporer. ${ }^{38}$

\footnotetext{
${ }^{35}$ Lihat Badri Khaeruman, Otentisitas Hadis Studi Kritis Atas Kajian Hadis Kontemporer, (Bandung: PT. Remaja Rosda Karya 2004), 124.

${ }^{36}$ Lihat H.A Mannan Buchari, Menyingkap Tabir Orientalisme, (Jakarta: AMZAH, 2006), 16.

${ }^{37}$ Lihat M.F Zenrif., Sintesis Paradigma Studi Al-Qur'an, (Malang: UIN Malang Press, 2008), 83

${ }^{38}$ Lihat H.A Mannan Buchari, Menyingkap Tabir Orientalisme, 15
} 
Gerakan orientalisme awalnya memiliki misi untuk menjajah negara dan agama Timur, dalam hal ini Islam. Tetapi seiring dengan perkembangan zaman, orientalisme pada akhirnya berpindah dan bergerak murni pada kajian dengan obyek hal bersifat ketimuran secara obyektif-independen. Alur perjalanan orientalisme itu, setidaknya, melalui tiga periode, yaitu periode sebelum perang salib, perang salib hingga masa pencerahan Eropa, dan periode terakhir adalah mulai pencerahan hingga zaman modern. ${ }^{39}$ Hal ini ditandai dengan kehadiran para orientalis di Timur (Islam) yang juga berfungsi sebagai penasehat kolonial, disamping melakukan kajian-kajian ilmiah. ${ }^{40}$ Di dalam mendiskusikan kajian Orientalis terhadap al-Qur'an, Pandangan utama orientalis terhadap al-Qurean adalah al-Qurean itu percampuran unsur-unsur perjanjian lama (old testament), perjanjian baru (new testament) dan berbagai sumber-sumber lain termasuklah pengaruh agama Yahudi. Al-Qurean juga biasanya dituduh sebagai bukan wahyu Tuhan, melainkan adalah karangan nabi Muhammad Saw, ini adalah dakwaan klasik yang telah terdengar sejak zaman nabi Muhammad Saw. W. M Watt mengatakan bahwa ajaran al-Qur"ean berasal dan kepunyaan tradisi Judaeo-Christian tentang konsep ketuhanan, kenabian, wahyu, hari akhirat dan penolakan terhadap penyembahan berhala, dan yang lebih menyedihkan lagi Watt menyebutkan bahwa Islam merupakan tradisi Yahudi dan Kristen. ${ }^{41}$ Secara umum kita dapat membagi mereka ke dalam dua kategori umum, yaitu pertama kelompok "old" Orientalism (Orientalisme "Masa Lalu"). Lihat saja Ignaz Goldziher yang wafat tahun 1921, Theodor Noldeke (m. 1930), Edward Sell (m. 1932), Arthur Jeffery (m. 1959).

Kelompok ini di dalam beberapa karyanya lebih mengutamakan kajian kepada what is behind the text (apa yang ada di balik teks/al-Qur'an). Karya Edward Sell yang berjudul Historical Development of the Qur'an, A. Mingana tentang Syiriac Influence on the Style of the Qur'an, A. Jeffery tentang The Foreign Vocabulary of the Qur'an, dan juga yang lain, masuk dalam kategori ini, karena membahas sesuatu sebelum al-Qur'an

${ }^{39}$ Lihat Arina Haqan, “Orientalisme Dan Islam Dalam Pergulatan Sejarah”, Dalam, Jurnal Mutawâtir, Vol.1

No.2 Desember 2011, 165.

${ }^{40}$ Lihat M.F Zenrif., Sintesis Paradigma Studi Al-Qur'an, 84

${ }^{41}$ Lihat W. M. Watt, Islam And The Integration Of Society, Cet. IV, (London: Routledge And Kegan Paul, 1970), 211 
terbentuk, seperti pengaruh luar terhadap al-Qur'an dan juga sejarah kemunculan alQur'an. ${ }^{42}$

Hal ini dilakukan dengan menggunakan metodologi filologi, textcriticism, form criticism dan lainnya. Banyak juga karya Orientalis yang tidak setuju dengan pandangan mereka dan mengajukan pandangan yang jauh berbeda. Bahkan, beberapa pengamat kajian al-Qur'an menyatakan bahwa saat ini telah terjadi "perubahan paradigma" (shift of paradigm) dalam kajian al-Qur'an. Kalau kajian kelompok pertama lebih terfokus pada what is behind the text (apa yang ada di belakang teks), sedangkan kajian kelompok yang kedua adalah fokus kepada what is before/in front of the text (apa yang ada di hadapan teks/al-Qur'an), seperti bagaimana al-Qur'an selalu memberikan pengaruh bagi para pembaca dan pendengarnya, dan bagaimana para pembaca/pendengar menerima dan memahami al-Qur'an. ${ }^{43}$

Munculnya kajian kritis terhadap Al-Qur'an disebabkan oleh adanya rasa kekecewaan dari beberapa cendekiawan orientalis barat atau Islamist (baca Kristen) terhadap apa yang ada pada kitab suci agama mereka (Bibel). Tidak sedikit di antara mereka yang mengeluhkan tentang adanya beberapa ragam versi Bibel yang ditulis oleh beberapa cendekiawan Kristen itu sendiri. Sebagian dari mereka terpaksa menerima kenyataan bahwa Bibel yang ada di tangan mereka sekarang ini terbukti tidak original lagi, tidak otentik dan bahkan palsu. Hal ini disebabkan karena terlalu banyak campur tangan gagasan penulis di dalamnya, menyebabkan sehingga sulit untuk membedakan mana yang murni wahyu dan mana yang bukan wahyu. ${ }^{44} \mathrm{Hal}$ ini selaran dengan yang ditegaskan oleh Kurt Aland dan Barbara Aland dalam buku The Text of the New Testament:

Until the biginning of the fourth century, the text of the newtestament developed freely. Even for later scribes, for example, the parallel passages of the Gospel where so familiar that they would adapt the text of one Gospel to that of another. They also felt themselves free to make corrections in the text, improving it by their own standard of correctness, whether grammatically, stylitically, or more substantively. ${ }^{45}$

\footnotetext{
${ }^{42}$ Lihat Stefan Wild, “Preface,” In The Qur'an As Text, Ed. S. Wild, (Leiden: Brill, 1996), Viii

${ }^{43}$ Lihat Yusuf Rahman, "Trend Kajian Al-Qur'an Di Dunia Barat”, Dalam Jurnal Studi Insania Vol.1 No.1 April 2013, 2

${ }^{44}$ Lihat Syamsuddin Arif, Orientalis \& Diabolisme Pemikiran (Jakarta: Gema Insani Press, Cet-I, 2008), 3

${ }^{45}$ Lihat Syamsuddin Arif, Orientalis \& Diabolisme Pemikiran, 3-4
} 
Banyak penulis Bibel, menurut Saint Jerome mengatakan bahwa di antara para cendekiawan Kristen menulis makna sesuai denga apa yang dipikirkan, bukan apa yang mereka jumpai sebagaimana aslinya. Hal ini lebih menambah kesalahan dan ketidak otentikan terhadap penulisan naskah teks Bibel. ${ }^{46}$ Melihat fenomena ini, Bruce M. Metzger menulis buku dengan judul The Text of the New Testament: Its Transmission, Corruption and Restoration. Juga dengan Manfred Heiligmann yang menulis Ada Apa dengan Alkitab? : Kesalahan, Absurditas, Inkonsitensi dan Vulgaritas dalam Alkitab (Jakarta: Bina Communio, cet. I, 2011). Selain mengkaji historisitas al-Qur'an, kalangan Orientalis juga melakukan kajian terhadap sejarah dari penafsiran al-Qur'an. Semangat baru dalam studi ilmu al-Qur'an (new spirit in Qur'anic Studies) ini telah melahirkan berbagai macam tulisan di Barat. Buku yang dianggap penting dan digunakan dalam kajian ini adalah Approaches to the History of the Interpretation of the Qur'an (Oxford 1988), yang diedit oleh Andrew Rippin (murid setia John Wansbrough), dan Approaches to the Qur'an (London 1993), diedit oleh G.R. Hawting. Al-Qur'an tidak hanya dikaji dari segi historisitas kesejarahan, teks dan manuskrip, tetapi juga dikaji dengan metode komparasi dengan kitab-kitab suci agama lain (Comparative Studies). Untuk kajian ini sendiri tidak hanya ditulis oleh kalangan orientalis saja, tetapi juga dari kalangan cendekiawan dan sarjana Muslim sendiri. Studi komparasi sebanarnya hanya akan memperlihatkan nilai lebih dan kekurangan dari sebuah obyek yang dikaji. Sebenarnya tidak perlu dibandingkan, karena dari segi historisitas sejarah, sumber, teks, bahasa, materi, kitab-kitab di dunia ini sangatlah berbeda-beda.

Studi perbandingan Al-Qur'an terhadap Bibel sangat tidak sesuai karena tidak setara. Al-Qur'an sendiri di dalam Islam setara dengan Isa atau Yesus dalam bahasa Kristen. Adapun Bibel sendiri yang merupakan laporan yang ditulis oleh murid-murid Isa, maka ia otoritasnya setara dengan hadis yang merupakan laporan sahabat terhadap apa yang disandarkan terkait perkataan, perbuatan, ketetapan, ataupun sifat-sifat kepada Nabi Muhammad saw. Hal ini tidak bisa direalisasikan karena sudah menyentuh ranah wilayah keimanan (belief). ${ }^{47}$ Dari sini jelas bahwa Wolfson tidak membandingkan Al-Qur’an

${ }^{46}$ Lihat Syamsuddin Arif, Orientalis \& Diabolisme Pemikiran, 4

${ }^{47}$ Dalam Islam, Al-Qur'an berasal dari Allah (Tuhan), sedangkan dalam Kristen yang berasal dari Tuhan adalah Yesus (Isa al-Masih) yang merupakan the Word of God atau the Son of God. Tidak heran jika Harry Wolfson dalam buku The Philosophy of Kalam mengatakan bahwa pentingnya Al-Qur'an bagi Kaum Muslim dan Islam sama pentingnya dengan pentingnya Yesus bagi umat Kristen (the importance of the Qur'an for Muslim and Islam is tantamount to the importance of the person of the Jesust Christ for Christians 
dengan Bibel atau Perjanjian Baru (New Testament), tetapi dengan Yesus sendiri. Dalam tradisi Kristen yang menjadi wahyu adalah Yesus sendiri, dan dalam Islam wahyu itu adalah al-Qur'an.

Dengan demikian, studi perbandingan antara Al-Qur'an dan Bibel merupakan kajian perbandingan yang Apple to apple (tidak sebanding). Meskipun demikian, banyak sarjana Barat yang mengadakan kajian studi perbandingan (comparative study) terhadap kedua kitab suci agama besar tersebut. Beberapa literatur yang mengkaji teks Al-Qur'an dari segi bahasa Al-Qur'an sendiri, ataupun dengan kitab suci agama lainnya. Di antara literatur itu adalah A Comparative Lexical Study of Qur'anic Arabic, karya Martin R. Zammit. The Bible, The Koran, and The Talmud karya Gustav Weil. Buku ini merupakan terjemahan darif bahasa Jerman.The Qur'an and the Gospels: A Comparative Study karya Muhammad M. Abu Laylah.

Beberapa sarjana Barat telah meneliti hubungan Bibel dan Al-Qur'an, seperti Reuven Firestone dalam artikelnya "The Qur'an and the Bible: Some Modern Studies of Their Relationship”, Vernon K. Robbins dan Gordon D. Newby; “A Prolegomenon to the Relation of the Qur'ān and the Bible”, John C. Reeves; "Some Explorations of the Intertwining of Bible and Qur'ān”, Brian M. Hauglid; "On the Early Life of Abraham: Biblical and Qur'ānic Intertextuality and the Anticipation of Muhammad', Between Bible and Qur'an: The Children of Israel and the Islamic Self-Image, karya Uri Rubin, dan lainlain.” Kajian kritis terhadap Al-Qur'an memang sudah banyak dilakukan oleh kalangan orientalis sebagaimana telah dilakukan terhadap Bibel.

\section{KESIMPULAN}

Sifat Al-Qur'an yang bersifat historis menyebabkan munculnya gagasan dan teori hermeneutika (metode penafsiran). Teori ini menjadi kerja-usaha yang sangat mendesak untuk dikembangkan dalam memahami makna Al-Qur'an secara utuh. Harapannya, bagian-bagian teologis dan etika legalnya dapat ditempatkan dalam keseluruhan (totalitas) yang padu. Melalui metode ini, sebuah weltanschauung (pandangan dunia) Al-Qur'an dapat dirumuskan dan dipahami. Bila manusia mau berpikir secara optimal dan mau memanfaatkan akal rasionalnya, ia akan menyadari bahwa sesungguhnya berkah AlQur'an yang teramat besar adalah pemikiran dan pemahaman maksud-maksud serta makna

and christianity. It has been rightly observed that the Christian consept of incarnation correspond to what one might call "illibration" in Islam) Lihat Muhammad Anshori, "Tren-Tren Wacana Studi Al-Qur'an Dalam Pandangan Orientalis Di Barat”, Dalam Jurnal Nun, Nun, Vol. 4, No.1, 2018. 36 
yang terkandung di dalamnya untuk kemudian mewujudkan gagasannya dalam perbuatan yang bersifat keagamaan dan keduaniaan. Dalam hal ini, kemudian Sahiron Syamsuddin, memetakan aliran metode studi qur'an kontemporer menjadi tiga kelompok:

a) Pandangan quasi-obyektivis tradisionalis, yakni suatu pandangan bahwa Al-Qur'an harus dipahami, ditafsirkan serta diaplikasikan pada masa kini, sebagaimana ia juga telah dipahami, ditafsirkan dan diaplikasikan pada situasi di mana Al-Qur'an diturunkan kepada Nabi Muhammad SAW dan disampaikan kepada para sahabatnya. Seluruh yang tertera secara literal dalam Al-Qur'an, menurut aliran ini, harus diaplikasikan juga di masa kini dan bahkan di masa yang akan datang.

b) Pandangan quasi-obeyektivis modernis, aliran ini juga memandang penting terhadap original meaning (makna asal), namun bagi kelompok ini, makna asal tersebut hanya sebagai pijakan awal untuk melakukan pembacaan terhadap Al-Qur'an di masa kini. Makna asal literal tidak lagi dipandang sebagai pesan utama Al-Qur'an. Karena itu, perangkat-perangkat metodis lain, seperti informasi tentang konteks sejarah makro dunia Arab saat penurunan wahyu, teori-teori ilmu bahasa dan sastra modern dan hermeneutika dibutuhkan dalam penafsiran ayat-ayat Al-Qur'an, sehingga makna di balik pesan tekstual, menurut kelompok ini, harus berusaha di ungkap.

c) Pandangan aliran subyektivis, yaitu aliran yang meyakini langkah penafsiran sepenuhnya merupakan subyektivitas penafsir. Karena itu, setiap generasi berhak menafsirkan Al-Qur'an sesuai dengan perkembangan dan pengetahuan.

Sesuai dengan ungkapan shalihun li kulli zaman wa makan, Al-Qur'an dipandang perlu ditafsirkan sesuai dengan konteks kondisi perkembangan zaman, akan tetapi perlu diingat pula latarbelakang historisnya yang nantinya ditarik penafsirannya di era sekarang. Menurut Sahiron, muslim saat ini harus juga berusaha memahami makna di balik pesan teks, yang disebut oleh Rahman dengan ratio legis, juga disebut dengan maqashid (tujuantujuan ayat) oleh al-Thalibi atau disebut maghza (signifikansi ayat) oleh Abu Zayd.

Studi ilmu al-Qur'an di Barat pertama kali dilakukan oleh kelompok orientalisme yang pada awal kemunculannya berkaitan erat dengan psiko-historis hubungan Islam dan Barat di bidang intelektual, perdagangan dan peperangan. Oleh karena itu, studi ilmu alQur'an dalam kajian orientalisme tidak hanya berorientasi pada hubungan emosiintelektual, melainkan juga emosi-politis ketimuran, yaitu dalam rangka memperlancar ekspansi politik Barat terhadap Timur. 
Jadi, fenomena orientalisme berkaitan erat dengan kolonialisme. Dimana ada kolonialisme, disitu ada orientalisme. Makin luasnya wilayah jajahan, maka meluas dan lebih dalam pula gerakan orientalisme. Meluasnya studi orientalisme, erat hubungannya dengan munculnya gerakan Islam kontemporer. Pada awal perkembangannya, orientalisme memiliki tujuan untuk menjajah negara dan agama Timur, dalam hal ini Islam. Tetapi seiring perkembangan zaman, orientalisme pada akhirnya bergerak murni pada kajian ketimuran secara obyektif-independen. Alur perjalanan orientalisme itu, setidaknya, melalui tiga periode, yaitu periode sebelum perang salib, perang salib hingga masa pencerahan Eropa, dan periode terakhir adalah mulai pencerahan hingga zaman modern.

\section{DAFTAR PUSTAKA}

A. K. Soleh, Membandingkan Hermeneutika Dengan Ilmu Tafsir, Tsaqafah, 7(1), 2011

A. Syukri, Metodologi Tafsir Al-Qur'an Kontemporer Dalam Pemikiran Fazlur Rahman. Kontekstualita: Jurnal Penelitian Sosial Keagamaan, 20(1), 2005.

Abd Muid, Dan M. A. Nawawi, Hermeneutika Kesadaran Dalam Memahami Teks AlQur'an, Al Amin: Jurnal Kajian Ilmu Dan Budaya Islam, 3(1), 2020

Abu Zayd, Nashr Hamid. Falsafah Al-Ta'wil: Dirasah Fi Ta'wil Al-Qur'an 'Inda Muhyiddin Ibn 'Arabi. Cet. I; (Beirut: Dar Al-Tanwir Li Al- Thiba'ah Wa AlNasyr, 1983)

Alawi, The Uslub of Tafsir Al-Quran. Journal Of Islamicate Studies, 1(1), 2018.

Almirzanah, Syafa'atun et. Al., Upaya Integrasi Hermeneutika Dalam Kajian Qur'an Dan Hadis: Teori Dan Aplikasi, (Yogyakarta: Lembaga Penelitian Uin Sunan Kalijaga Yogyakarta, 2009)

Anshori, Muhammad, "Tren-Tren Wacana Studi ilmu al-Qur'an Dalam Pandangan Orientalis Di Barat”, Dalam Jurnal Nun, Nun, Vol. 4, No.1, 2018.

Arif, Syamsuddin, Orientalis \& Diabolisme Pemikiran (Jakarta: Gema Insani Press, Cet-I, 2008)

Buchari, H.A Mannan, Menyingkap Tabir Orientalisme, (Jakarta: AMZAH, 2006)

H. Yasin, Mengenal Metode Penafsiran Al Quran, Tahdzib Al-Akhlaq: Jurnal Pendidikan Islam, 3(1), 2020.

Haqan, Arina, "Orientalisme Dan Islam Dalam Pergulatan Sejarah", Jurnal Mutawâtir, Vol.1 No.2 Desember 2011

Idri, Studi Hadis, (Jakarta: Kencana, 2010)

Izzan, Ahmad, Ulumul Qur'an: Telaah Tekstualitas Dan Kontekstualitas Al-Qur'an, (Bandung: Tafakur, 2011)

Kau, S.A. Hermeneutika Gadamer Dan Relevansinya Dengan Tafsir, Farabi, 11(2), 2014

Khadhar, Lathifah Ibrahim, Ketika Barat Memfitnah Islam, (Jakarta; Gema Insani, 2005)

Khaeruman, Badri, Otentisitas Hadis Studi Kritis Atas Kajian Hadis Kontemporer, (Bandung: PT. Remaja Rosda Karya 2004)

L. Muttaqin, Aplikasi Teori Double Movement Fazlur Rahman Terhadap Doktrin Kewarisan Islam Klasik, Al-Manahij: Jurnal Kajian Hukum Islam, 7(2), 2013. 
M. Abu Laylah, Muhammad M., The Qur'an And The Gospels: A Comparative Study, (Kairo: Al-Falah Foundation For Translation, Publication \& Distribution, Cet-III, $1426 \mathrm{H} / 2005 \mathrm{M})$.

M. I. Helmy, Kesatuan Tema Dalam Al-Qur'an: Telaah Historis-Metodologis Tafsir Maudhu'iy. Jurnal Ilmiah Ilmu Ushuluddin, 19(2), 2020.

Mustaqim, Abdul, Epistemologi Tafsir Kontemporer, (Yogyakarta: Lkis, 2012)

Mustaqim, Abdul, et. Al., Studi ilmu al-Qur'an Kontemporer, Wacana Baru Berbagai Metodologi Tafsir (Yogyakarta: Tiara Wacana, 2012)

Nugroho, I. Y. (2020). Orientalisme dan Hadits: Kritik Terhadap Sanad Menurut Pemikiran Joseph Schacht. Asy-Syari'ah: Jurnal Hukum Islam, 6 (2), 155-170.

R. A. Sumantri, Hermeneutika Al-Qur'an Fazlur Rahman Metode Tafsir Double Movement, Komunika: Jurnal Dakwah Dan Komunikasi, 7(1), 2013.

R. Irawan, Metode Kontekstual Penafsiran Al-Qur'an Perspektif Fazlur Rahman. AlDzikra: Jurnal Studi Ilmu Al-Qur'an Dan Al-Hadits, 13(2), 2019.

Rabbani Dan Fanani, Metode Tafsir Al-Qur'an Kontemporer, Wahana Islamika: Jurnal Studi Keislaman, 3(2), 2017.

Rahman, Yusuf, "Trend Kajian Al-Qur'an Di Dunia Barat”, Dalam Jurnal Studi Insania Vol.1 No.1 April 2013

Rubin, Uri, Between Bible And Qur'an: The Children Of Israel And The Islamic SelfImage, (Princeton: The Darwin Press, 1999).

S. Rokim, Mengenal Metode Tafsir Tahlili. Al-Tadabbur: Jurnal Ilmu Al-Qur'an Dan Tafsir, 2(3), 2017.

S. Tjahyadi, Manusia Dan Historisitasnya Menurut Martin Heidegger, Jurnal Filsafat, 18(1), 2018

Shihab, Quraish, Membumikan Al-Qur'an (Bandung: Mizan, 1994)

Sou'yb, Joesoef, Orientalisme Dan Islam, (Jakarta: Bulan Bintang, 1995)

Syahrur, Muhammad, Prinsip Dan Dasar Hermeneutika Al-Qur'an Kontemporer, (Yogyakarta: Teras, 2008)

Syamsuddin, Sahiron, Hermeneutika Al-Qur'an Dan Hadist (Yogyakarta; Elsaq Press, 2010)

Syafi'i, Imam. (2020). Konsep Kafa'ah dan Keluarga Sakinah (Studi Analisis Tentang Korelasi Hak Kafa'ah Terhadap Pembentukan Keluarga Sakinah). Asy Syari'ah: Jurnal Hukum Islam. 6 (1), 31-48.

Watt, W. M., Islam And The Integration Of Society, Cet. IV, (London: Routledge And Kegan Paul, 1970)

Weil, Gustav, The Bible, The Koran, And The Talmud, (London: Longman,Brown, Green, Longmans, 1846).

Wild, Stefan, "Preface," In The Qur'an As Text, Ed. S. Wild, (Leiden: Brill, 1996)

Yamani, M. T., Memahami Al-Qur'an Dengan Metode Tafsir Maudhu'i, J-PAI: Jurnal Pendidikan Agama Islam, 1(2), 2015.

Zammit, Martin R., A Comparative Lexical Study Of Qur'anic Arabic, (Leiden-Boston: Brill, 2002).

Zenrif, M.F, Sintesis Paradigma Studi ilmu al-Qur'an, (Malang: UIN Malang Press, 2008)

Zulaiha, Tafsir Kontemporer: Metodologi, Paradigma Dan Standar Validitasnya, Wawasan: Jurnal Ilmiah Agama Dan Sosial Budaya, 2(1), 2017. 